\title{
Physicochemical, microbiological and sensory characteristics of fish sauce from spined anchovy (Stolephorus tri)
}

\author{
TANIM KHAIR, MASHIOUR MAHMUD KHAN, \\ MOHAMMED NURUL ABSAR KHAN ${ }^{1}$ AND MD. SHAHEED REZA* \\ Department of Fisheries Technology, Bangladesh Agricultural University, Mymensingh 2202, Bangladesh \\ ${ }^{1}$ Department of Fishing and Post-Harvest Technology, \\ Chattogram Veterinary and Animal Sciences University, Chattogram, Bangladesh \\ *Email: msreza@bau.edu.bd
}

\begin{abstract}
Recently, the consumer demand for imported Thai fish sauce is increasing in Bangladesh domestic market. To satisfy potential consumer demand, underutilized marine fish of the Bay of Bengal can be used in this regard to produce fish sauce locally. A study was, therefore, undertaken to prepare fish sauce from underutilized spined anchovy (Stolephorus tri, locally called 'kata phasha') using $25 \%$ (w/w) salt in earthen containers and characterized essential quality parameters. Fermentation was continued for 7 months, and physicochemical, microbiological, and sensory characteristics of the product during processing were studied. At the end of fermentation, moisture and mineral content of the sauce reached to high values of $68.54 \pm$ $0.35 \%$ and $22.56 \pm 0.35 \%$, respectively with a concomitant decrease in protein $(5.03 \pm 0.05 \%)$. Total volatile base nitrogen (TVB-N) and total nitrogen (TN) values, on the other hand, reached $18.42 \pm 0.00 \mathrm{mg} / 100 \mathrm{~g}$ and $0.76 \pm 0.02 \mathrm{~g} \mathrm{~N} / 100 \mathrm{ml}$, respectively with a relatively high bacterial load of $7.14 \pm 0.02 \mathrm{log} \mathrm{cfu} / \mathrm{ml}$. Sensory evaluation conducted by a group of untrained panelists revealed high acceptability of the fish sauce in terms of colour, flavour, taste (e.g. saltiness, bitterness, sweetness, sourness and umami), clearness, liquidity and overall acceptability. It is concluded that low-valued fish like spined anchovy of the Bay of Bengal can be used as a raw material to produce good quality fish sauce.
\end{abstract}

Keywords: Bay of Bengal, Fish sauce, Anchovy, Value-addition

\section{Introduction}

In fish processing, fermentation implies the breakdown of proteins in the fresh fish to simpler substances under anaerobic conditions or low oxygen levels (Lopetcharat et al. 2001) that are stable at room temperature during storage. The products are generally produced by conventional method, mixing small fishes with salt and stored underground in earthen or concrete containers for prolonged period (Wichaphon et al. 2013). Upon fermentation, partial breakdown of protein takes place that produces volatile compounds responsible for its unique aroma (Zheng et al. 2017). Breakdown of proteins is brought about by the action of endogenous (originating from the digestive tract, muscle tissue) and bacterial enzymes that converts fish muscle protein and other organic materials into simpler compounds (Chaveesuk 1991, Beddows 1998). Different strains of lactic acid bacteria, halophilic and halotolerant bacteria multiply during fermentation and take part in fermentation process (Ly et al. 2020). These are rich in essential amino acids (EAAs), polypeptides, B-vitamins, polyunsaturated fatty acids and minerals (Peralta et al. 2008). The product is very popular in Southeast Asia, and now has spread across the globe including Bangladesh. 
In Bangladesh, three types of fermented fish products viz., shidhal or shidal (semifermented barbs), shidil (dried, semi-fermented small fishes) and nga-pi (semi-fermented shrimp paste) are produced locally and consumed by people of many parts of the country (Alam 2007, Nayeem et al. 2010a, Nayeem et al. 2010b, Mansur et al. 2014). They are very popular food condiments and considered as a good source of protein (Mansur 2007). The processing methods used for fermentation of these products dates back hundreds of years, as early as 1824 , where conventional methods are used for their production. Traditionally, fishermen adopted these simple technologies to preserve their bulk catch of small fishes e.g. barbs (Puntius spp., Esomus spp.), small-sized bagrid catfishes (Mystus spp.), leaffish (Nandus sp.), gouramies (Colisa sp.) and shrimp, particularly during the peak fishing season (Alam 2007). Due to the adaptability with these semi-fermented products, consumers in Bangladesh recently started using fish sauce. Although comparatively new in Bangladesh, they are now being widely used as an important ingredient of Bangladeshi cuisine in households as well as restaurants in the capital Dhaka and other major cities. The fish sauce used in Bangladesh is mainly imported from Thailand, Vietnam, and China. Low-valued marine fish species including anchovy (Stolephorus spp.), mackerel (Rastrelliger spp.), and herring (Clupea spp.) are regarded as the most suitable species for the production of fish sauce. According to the Thai Public Health Ministry, fish sauces in Thailand are classified into three types: (i) pure fish sauce (ii) hydrolyzed fish sauce, and (iii) diluted fish sauce (Wilaipan 1990). Among these three, pure fish sauce the most expensive product as it is derived from fresh fish or fish residue obtained during salt fermentation of fish. The other two products are relatively cheaper as they are either obtained from the hydrolysates of fish or other animals or by dilution of fish sauce with water or approved additives. In all cases, fish is first graded, washed and whole un-eviscerated fish is mixed with salt to fish at a ratio ranging from 1:6 to 1:2 (w/w) (Lopetcharat and Park 2002). Then they are stored in underground concrete tanks or earthenware/earthen jars for 6-12 months at ambient temperature to complete the hydrolysis process. Homemade fish sauce in Thailand is also prepared by grinding the fish, pressing by hand and placing fish into clay jars in alternative layers of fish and salt. Although the technology is simple, the process needs to be optimized as several factors including fish species, types and the ratio of salt used and condition of fermentation influence the quality of fish sauce (Anihouvi et al. 2011). Until now, only a few studies in Bangladesh have been conducted that used low-valued freshwater fish species as raw material for making the fish sauce (Faisal et al. 2013). So, there is a need to explore the usefulness of other freshwater and marine fishes with low-value such as anchovies to meet the growing domestic consumer demand.

In the Bay of Bengal, large quality of spined anchovy (S. tri, locally called 'kata phasha') is harvested every year using set bag net. Although a large portion of the harvested fish species is consumed in fresh condition, the remaining portion sometimes is sun-dried or used as raw material for animal feeds. So, there is good scope to utilize this species as a raw material of fish sauce. The present study was, therefore, undertaken to prepare fish sauce from this low-valued under-utilized species in traditional earthen container and characterize its physiochemical and microbiological properties.

\section{Materials and Methods}

Fish: Market sized spined anchovy Stolephorus tri (Fig. 1A) caught by marine set bag net were collected from Cox's Bazar and transported to the Post-Graduate Laboratory, Department of 
Fisheries Technology, Bangladesh Agricultural University (BAU), Bangladesh in iced condition at a ratio of fish:ice $=1: 1(\mathrm{w} / \mathrm{w})$.

Preparation of fish sauce: Fish samples were washed properly with chilled freshwater, dewatered for $15 \mathrm{~min}$ and divided into 3 (three) parts of $1.5 \mathrm{~kg}$ each to be used as triplicates. For the present experiment, table salt at a concentration of $25 \%(\mathrm{w} / \mathrm{w}, \mathrm{NaCl})$ was selected based on the previous results of higher sensory acceptability for fish sauce produced using that salt concentration. As such, the samples were mixed with $25 \%(\mathrm{w} / \mathrm{w}, \mathrm{NaCl}$ ) thoroughly. Then they were packed into previously cleaned and sterilized earthen containers (Fig. 1B, 1C) and kept in a dry place for 7 months for fermentation. All samples were stirred manually using stainless steel ladle at every 15 days of fermentation. After completion of fermentation, the liquid part was filtered and aged in the direct sunlight for 7 days. Thus, the fish sauce became ready to use.

Sampling procedure: During manual stirring, representative samples were collected for analysis at days $15,30,45,60,75,90,105,120,135,150,165,180,195$ and 210 . Then they were flittered using filter paper (Whatman No. 5) and subjected to biochemical and microbiological analyses. All analyses were carried out in triplicates.

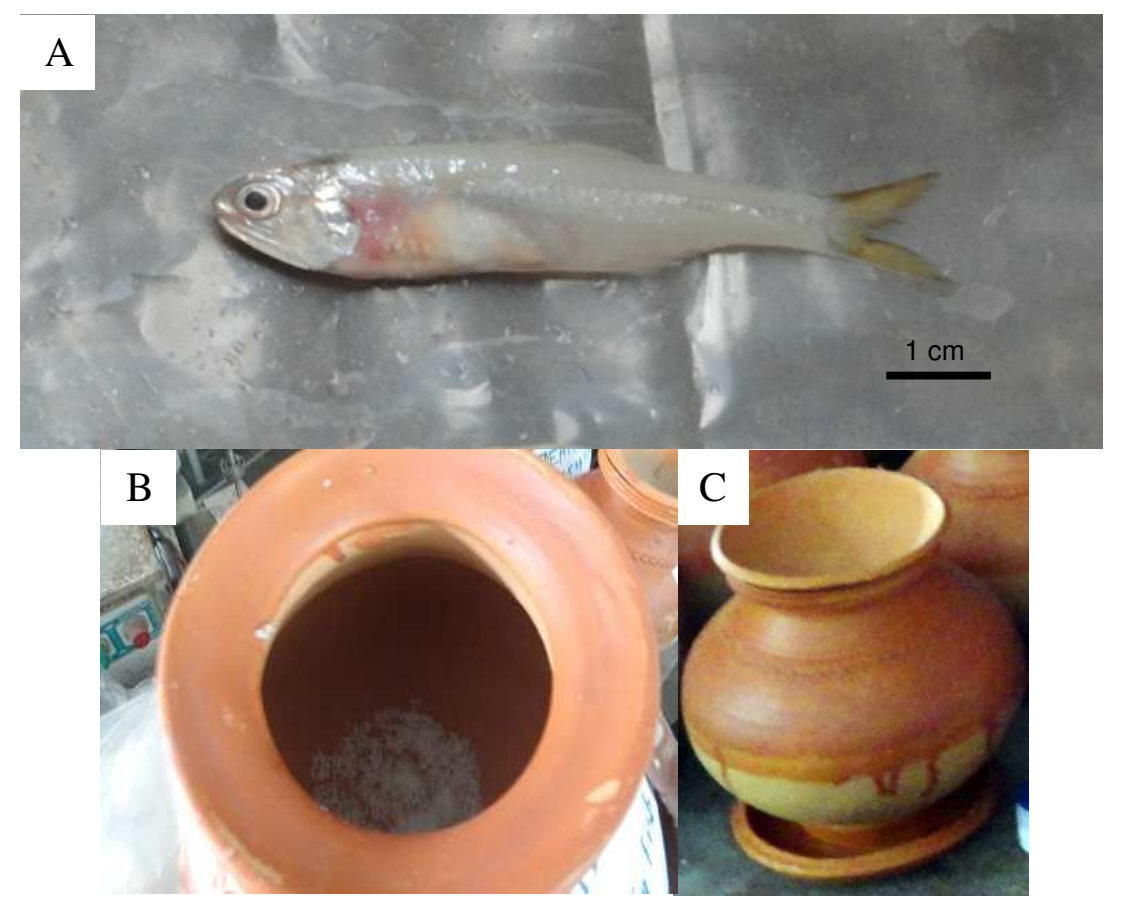

Fig. 1. Salt-fermentation of (A) spined anchovy (Stolephorus tri) using $(\mathrm{B}, \mathrm{C})$ earthen container to produce fish sauce.

Physicochemical analyses of raw material: Three representative fresh fish samples were separated at the start of the fermentation process, mixed together and ground in a mechanical grinder to make a paste. This ground sample was used for all biochemical and bacteriological 
analyses. Among the biochemical parameters, initial TVB-N and total nitrogen (TN) were determined and expressed in $\mathrm{mg} / 100 \mathrm{~g}$ and $\mathrm{gN} / 100 \mathrm{ml}$ sample, respectively as described by AOAC (1990). Briefly, $10 \mathrm{~g}$ of sample was mixed with $90 \mathrm{ml}$ of $6 \%$ perchloric acid, steam distillated in a Kjeldahl flask with $10 \mathrm{ml}$ of $20 \% \mathrm{NaOH}$ and was absorbed by $50 \mathrm{ml}$ of $3 \% \mathrm{H}_{3} \mathrm{BO}_{3}$. The concentration of the bases was determined by titration with $0.01 \mathrm{~N} \mathrm{HCl}$. In order to determine TN, $5 \mathrm{~g}$ of sample was taken and diluted with $100 \mathrm{ml}$ of distilled water. Then $5 \mathrm{ml}$ of the solution was placed in a $125 \mathrm{ml}$ Erlenmeyer flask and $1 \mathrm{ml}$ of $2 \%$ potassium chromate solution was added to it. The solution was titrated with a $1 / 50 \mathrm{~N}$ silver nitrate solution to a light orange endpoint. The percentage of salt was then calculated using the formula: $\mathrm{NaCl} \%=\mathrm{A} \times$ $0.00117 \times \mathrm{F} \times \mathrm{C} \times \mathrm{DF}$ (where $\mathrm{A}=$ titration value, $\mathrm{F}=$ factor of $1 / 50$ silver nitrate, $\mathrm{C}=$ correction constant and $\mathrm{DF}=$ dilution factor). The proximate composition including moisture, crude protein, lipid, and ash contents of raw material were determined according to Islami et al. (2014). All analyses were carried out in triplicate.

Bacteriological analyses of raw material: The aerobic plate count (APC) of the fish samples was determined. Briefly, fish sample was homogenized first in a previously sterilized mortar and transferred into sterile test tube. Serial tenfold dilutions were prepared in $0.85 \% \mathrm{NaCl}$, and 0.1 $\mathrm{ml}$ aliquots were spread plated onto agar plates (Himedia, India) containing 2.0\% agar according to Mannan et al. (2020). The plates were incubated overnight at $30^{\circ} \mathrm{C}$ for $48 \mathrm{hrs}$. Only the plates having 30 to 300 colonies were considered to calculate bacterial population numbers and expressed as colony-forming units per unit of sample. Each count was the mean value of viable colonies appearing in duplicate agar plates made per individual sample.

Physico-chemical and bacteriological analyses of periodic samples and the end product: The physico-chemical and bacteriological parameters for the periodic samples and the end product were also determined as described previously.

Sensory analysis: Sensory analysis was conducted with 20 untrained panelists (aged between 30 to 60; men: women $=2: 1$ ) at the Department of Fisheries Technology, BAU. Samples were served to panelists and various attributes such as colour, flavour, taste, clearness, liquidity, and overall acceptability were evaluated based on a 7-point descriptive scale in the hedonic scale scoring method $(1=$ extremely undesirable and $7=$ extremely desirable $)$ with slight modifications (Soewarno 1985).

Statistical analysis: Data were tabulated and computed using MS Excel 2013 (Microsoft Corp. USA). Analysis of variance (ANOVA) was used to determine the presence of significant differences $(p<0.05)$ among sample groups.

\section{Results and Discussion}

Changes in physicochemical characteristics during fermentation: Changes in important physicochemical parameters of fish sauce during the entire fermentation period were determined and results are shown in Table I. The mean value of TVB-N in fresh samples of spined anchovy was $0.01 \pm 0.00 \mathrm{mg} / 100 \mathrm{~g}$. This initial value was found to be lower than those reported for other marine fishes found in the Bay of Bengal (Reza et al. 2009) which indicating good quality of raw material were used in the study. After the addition of $25 \%$ salt, a sharp rise in TVB-N 
PHYSICOCHEMICAL, MICROBIOLOGICAL AND SENSORY CHARACTERISTICS OF FISH SAUCE

was recorded that finally reached a significantly high value $(p<0.05)$ of $18.42 \pm 0.00 \mathrm{mg} / 100 \mathrm{~g}$ when fermentation was terminated after 7 months. Generally, the presence of TVB-N in fishery products indicates the degree of protein degradation by bacterial activity and hence bacterial fermentation. In fermented fish, TVB-N is the combined amount of ammonia, dimethylamine, and trimethylamine.

Table I. Changes in biochemical and proximate composition of salt-fermented spined anchovy during 7-month fermentation period

\begin{tabular}{|c|c|c|c|c|c|c|c|}
\hline \multirow{2}{*}{$\begin{array}{l}\text { Fermen- } \\
\text { tation } \\
\text { days }\end{array}$} & \multicolumn{3}{|c|}{ Biochemical parameters } & \multicolumn{4}{|c|}{ Proximate composition } \\
\hline & $\begin{array}{c}\text { TVB-N } \\
(\mathrm{mg} / 100 \mathrm{~g})\end{array}$ & $\begin{array}{c}\mathrm{TN} \\
(\mathrm{g} \mathrm{N} / 100 \mathrm{ml})\end{array}$ & $\begin{array}{l}\text { Salt } \\
(\%)\end{array}$ & $\begin{array}{c}\text { Moisture } \\
(\%)\end{array}$ & $\begin{array}{c}\text { Crude protein } \\
(\%)\end{array}$ & $\begin{array}{c}\text { Lipid } \\
(\%)\end{array}$ & $\begin{array}{l}\text { Ash } \\
(\%)\end{array}$ \\
\hline 0 & $0.01 \pm 0.00^{a}$ & $2.90 \pm 0.01^{\mathrm{a}}$ & $25.00 \pm 0.05$ & $70.28 \pm 0.22^{a}$ & $19.14 \pm 0.65^{\mathrm{a}}$ & $3.75 \pm 0.20$ & $10.31 \pm 0.25^{\mathrm{a}}$ \\
\hline 15 & $4.10 \pm 0.00^{b}$ & $4.48 \pm 0.01^{\mathrm{b}}$ & ND & $54.20 \pm 0.31^{\mathrm{b}}$ & $29.54 \pm 0.40^{\mathrm{b}}$ & ND & $19.42 \pm 0.90^{\mathrm{b}}$ \\
\hline 30 & $7.15 \pm 0.00^{\mathrm{c}}$ & $4.25 \pm 0.02^{\mathrm{b}}$ & ND & $60.48 \pm 0.35^{\mathrm{c}}$ & $28.03 \pm 0.43^{\mathrm{b}}$ & ND & $16.50 \pm 0.91^{\mathrm{b}}$ \\
\hline 45 & $9.15 \pm 0.01^{\mathrm{d}}$ & $3.94 \pm 0.01^{b}$ & ND & $61.86 \pm 0.25^{\mathrm{c}}$ & $25.98 \pm 0.92^{\mathrm{c}}$ & ND & $12.16 \pm 0.12^{\mathrm{c}}$ \\
\hline 53 & $10.47 \pm 0.02^{\mathrm{d}}$ & $3.42 \pm 0.01^{\mathrm{b}}$ & ND & $62.36 \pm 0.80^{\mathrm{c}}$ & $22.6 \pm 0.95^{\mathrm{d}}$ & ND & $12.13 \pm 0.54^{\mathrm{c}}$ \\
\hline 60 & $12.24 \pm 0.01^{\mathrm{d}}$ & $2.78 \pm 0.02^{\mathrm{b}}$ & ND & $63.12 \pm 0.60^{\mathrm{c}}$ & $18.34 \pm 0.85^{\mathrm{d}}$ & ND & $13.21 \pm 0.45^{\mathrm{c}}$ \\
\hline 75 & $13.41 \pm 0.01^{\mathrm{d}}$ & $2.61 \pm 0.00^{\mathrm{b}}$ & ND & $63.7 \pm 0.26^{\mathrm{c}}$ & $17.21 \pm 0.65^{\mathrm{d}}$ & ND & $14.66 \pm 0.45^{\mathrm{c}}$ \\
\hline 90 & $15.27 \pm 0.01^{\mathrm{d}}$ & $2.43 \pm 0.02^{\mathrm{b}}$ & ND & $63.31 \pm 0.90^{\mathrm{c}}$ & $16.03 \pm 0.90^{\mathrm{d}}$ & ND & $16.45 \pm 0.21^{\mathrm{c}}$ \\
\hline 105 & $15.59 \pm 0.01^{\mathrm{d}}$ & $2.44 \pm 0.01^{b}$ & ND & $63.63 \pm 0.52^{\mathrm{c}}$ & $16.12 \pm 0.80^{\mathrm{d}}$ & ND & $16.79 \pm 0.20^{\mathrm{c}}$ \\
\hline 120 & $16.24 \pm 0.01^{\mathrm{d}}$ & $2.370 .01^{\mathrm{b}}$ & ND & $64.91 \pm 0.45^{\mathrm{c}}$ & $15.63 \pm 0.25^{\mathrm{d}}$ & ND & $16.56 \pm 0.35^{\mathrm{c}}$ \\
\hline 135 & $17.36 \pm 0.01^{d}$ & $2.02 \pm 0.02^{b}$ & ND & $64.22 \pm 0.45^{\mathrm{c}}$ & $13.32 \pm 0.20^{\mathrm{d}}$ & ND & $16.92 \pm 0.86^{\mathrm{c}}$ \\
\hline 150 & $17.87 \pm 0.01^{\mathrm{d}}$ & $1.99 \pm 0.01^{\mathrm{c}}$ & ND & $65.57 \pm 0.08^{d}$ & $13.14 \pm 0.21^{\mathrm{d}}$ & ND & $16.59 \pm 0.25^{\mathrm{c}}$ \\
\hline 165 & $17.02 \pm 0.01^{\mathrm{d}}$ & $1.81 \pm 0.00^{\mathrm{c}}$ & ND & $65.58 \pm 0.15^{\mathrm{d}}$ & $11.93 \pm 0.30^{\mathrm{e}}$ & ND & $17.09 \pm 0.28^{d}$ \\
\hline 180 & $18.13 \pm 0.00^{\mathrm{d}}$ & $1.47 \pm 0.01^{\mathrm{c}}$ & ND & $68.32 \pm 0.28^{\mathrm{d}}$ & $9.73 \pm 0.20^{\mathrm{e}}$ & ND & $19.51 \pm 0.82^{\mathrm{d}}$ \\
\hline 195 & $18.42 \pm 0.00^{\mathrm{d}}$ & $0.95 \pm 0.01^{\mathrm{d}}$ & ND & $68.14 \pm 0.20^{d}$ & $6.28 \pm 0.22^{\mathrm{e}}$ & ND & $20.66 \pm 0.22^{\mathrm{d}}$ \\
\hline 210 & $18.42 \pm 0.00^{\mathrm{d}}$ & $0.76 \pm 0.02^{\mathrm{d}}$ & $23.89 \pm 0.85$ & $68.54 \pm 0.35^{\mathrm{d}}$ & $5.03 \pm 0.05^{\mathrm{f}}$ & $3.5 \pm 0.10$ & $22.56 \pm 0.35^{\mathrm{e}}$ \\
\hline
\end{tabular}

Although the value of TVB-N depends on the composition of bacterial flora and the method of analysis (Antonacopoulos and Vyncke 1989), the values of the end product were well below the acceptable limit for fresh fish $(20 \mathrm{mg} / 100 \mathrm{~g})$ as well as dried and salted fishery products (100 to $200 \mathrm{mg} / 100 \mathrm{~g}$ ) (Connell 1995, FDA 2004). The salt concentration in the prepared sauces had a value ranging from $23.89 \pm 0.85 \%$ and the relatively low TVB-N value. Some other researchers have also reported wide range of TVB-N values $(210-375 \mathrm{mg} / 100 \mathrm{~g})$ in fermented fish products (Anihouvi et al. 2006, Roy et al. 2014) while Moini and Koochekian (2003) reported $25 \mathrm{mg} / 100 \mathrm{~g}$ for sauce made from kilka fishes of the Caspian Sea using 3 different preparations (whole kilka, cooked whole kilka and dressed kilka) after 6 months of fermentation. A very high TVB-N value of $226.80 \mathrm{mg} / 100 \mathrm{~g}$ was reported form fish sauce obtained from tuna (Thunnus albacares) viscera with $10 \% \mathrm{NaCl}$ (Besas and Dizon 2012). These high values are also reflected well by the bacterial load observed in the end product and a varying level of salt content. It is, therefore, predicted that the relatively lower TVB-N values in the end product are probably attributed to the preservative activity of salt.

Total nitrogen $(\mathrm{TN})$ values were found to be significantly influenced during the 210-day fermentation period at room temperature. This is used as an objective index that shows the quality of fermented products (Wilaipan 1990) where high value is an indication of better quality fish sauce. Initially, the TN value for spined anchovy sample was $2.90 \pm 0.01 \mathrm{~g} \mathrm{~N} / 100 \mathrm{~g}$ which showed a significant decrease $(p<0.05)$ to reach a value of $0.76 \pm 0.02 \mathrm{~g} \mathrm{~N} / 100 \mathrm{~g}$ on 210 -days 
of fermentation (Table I). Interestingly, there was a sharp increase in TN value on day 7 (4.48 $\pm 0.01 \mathrm{~g} \mathrm{~N} / 100 \mathrm{~g}$ ) that may be linked to the immediate release of water-soluble protein fraction from fish muscle cells. TN content was significantly affected by the days of fermentation $(p<0.05)$. Such release of soluble protein takes place due to the increased osmotic pressure resulting from the addition of salt for processing (Lopetcharat and Park 2002). A relatively lower TN value of fish sauce also indicates a lower level of crude protein in the sample. These $\mathrm{TN}$ values were found to be gradually decreased to reach a final value of $0.76 \pm 0.02 \mathrm{~g} \mathrm{~N} / 100$ g. Sanchez (2008) and Lawrie (1998) reported that a decrease in TN values was linked to Maillard reactions or due to changes in $\mathrm{pH}$. Although we did not estimate $\mathrm{pH}$ in the present study, we predict that the strong degradation of anchovy muscles occurred during the fermentation process due to the action of enzymes.

The salt content of spined anchovy sauce was recorded at two periods: at the start and end of the fermentation process. It was observed that the initial value of $25.00 \pm 0.05 \%$ salt did not show any significant change and reached a more or less similar value of $23.89 \pm 0.85 \%$ (Table I). Generally, salt content in fish sauce remains constant. The majority of the commercial fish sauce available in the domestic market of Asian markets as well as Bangladesh had salt content ranging from 24.1-30.6\% (Cho et al. 2000). In the present study, we purposefully used 25\% $(\mathrm{w} / \mathrm{w})$ salt for the fermentation process, which is more or less similar for those reported by others (Tungkawachara et al. 2003, Ulfah 2013).

Table I shows that the initial moisture content was $70.28 \pm 0.22 \%$ at day- 0 for fresh spined anchovy samples. This value showed a rapid and significant decrease $(p<0.05)$ to $54.20 \pm$ $0.31 \%$ for the first 15 days and to $60.48 \pm 0.35 \%$ for the second 15 days of the fermentation. With the progress of fermentation process, moisture level did not show any significant change $(p>0.05)$ and after 210 days the value again reached to the maximum level of68.54 $\pm 0.35 \%$. This gradual increase in moisture occurred due to the entrance of moisture inside the fish muscle and liquefaction of proteins which is more or less similar to those reported by Kim et al. (1999) who stated moisture percentage of anchovy and small fish sauce to be $46-77 \%$ and within the limit of $62-74 \%$ moisture for commercial fish sauces (Bersamin and Napugan 1961). When the changes in crude protein content during fermentation of spined anchovy was monitored, it was found that the value showed an increase from the initial $19.14 \pm 0.65 \%$ to $29.54 \pm 0.40 \%$, presumably due to release of soluble protein in the solution. As time passed the protein in the fish body started to liquefy and at the end of fermentation, crude protein reached a significantly lower value of $5.03 \pm 0.05 \%$, indicating medium-protein sauce as indicated by Wilaipan (1990). Ash content, on the other hand, was $10.31 \pm 0.25 \%$ in fresh fish samples that showed a significant rise on day $15(p<0.05)$. The high initial ash content in fresh fish is probably due to the fact that bones and scales were included in the analysis (Taorem and Sarojnalini 2011). Then increase in ash content during the later stages is linked to the absorption of $\mathrm{NaCl}$ by fish tissues. As time passed the fish muscle gradually hydrolyzed but the bones in the fish body remained intact. As a result, the ash content gradually increased to $22.56 \pm 0.35 \%$ (Table I). These results are more or less similar to those for Peda where the ash content in the end product ranged between 15.96-16.90\% (Desniar et al. 2009). Lipid content, however, did not show any significant change during the fermentation process.

Changes in microbiological characteristics during fermentation: Changes in viable bacteria in terms of aerobic plate count in fish samples during fermentation were estimated and shown in 
Table II. Due to the effect of $25 \%$ salt treatment, bacterial load showed a significant $(p<0.05)$ decrease from the initial value of $6.78 \pm 0.48 \mathrm{log} \mathrm{cfu} / \mathrm{g}$ to $5.08 \pm 0.25 \mathrm{log} \mathrm{cfu} / \mathrm{ml}$. These data are relatively higher than previous reports on anchovy where the initial bacterial load was about 2.0 $\log \mathrm{cfu} / \mathrm{g}$ (Wilaipan 1990, Ijong and Ohta 1996). This is possibly linked to the initial bacterial load of the raw materials that were transported to the laboratory in ice. On day 45 , the bacterial load showed a sudden decrease. At the end of the fermentation on day 210, bacterial load reached to a significantly higher value (Table II). This indicates that the addition of salt killed the majority of the salt-sensitive bacteria at the initial stages, after which halophilic bacteria present in salt gradually adjusted and multiplied. Multiplication was accelerated due to breakdown of macromolecular compounds that released the low molecular weight compounds. Generally, lactic acid bacterial (LAB) content increases due to the addition of salt. Thapa et al. (2004) reported that as high as $100 \%$ salt addition increased LAB up to $1.74 \mathrm{log} \mathrm{cfu} / \mathrm{g}$ in traditional fermented fishes while Al-Jedah et al. (2000) reported APC values in fish sauce to be $12.6 \mathrm{log} \mathrm{cfu} / \mathrm{ml}$ after 240 days of fermentation. These results suggest that bacterial load in the fish sauce prepared from spined anchovy was different from those reported by other studies.

Table II. Changes in bacterial load of salt-fermented spined anchovy during 7-month fermentation period

\begin{tabular}{cc}
\hline $\begin{array}{c}\text { Fermentation } \\
\text { days }\end{array}$ & $\begin{array}{c}\text { Aerobic plate count } \\
(\log \text { CFU/g or ml })\end{array}$ \\
\hline 0 & $6.78 \pm 0.48^{\mathrm{a}}$ \\
15 & $5.08 \pm 0.25^{\mathrm{b}}$ \\
30 & $5.72 \pm 0.71^{\mathrm{b}}$ \\
45 & $6.07 \pm 0.05^{\mathrm{b}}$ \\
60 & $6.46 \pm 0.12^{\mathrm{b}}$ \\
75 & $6.57 \pm 0.07^{\mathrm{b}}$ \\
90 & $6.76 \pm 0.01^{\mathrm{c}}$ \\
105 & $6.85 \pm 0.04^{\mathrm{c}}$ \\
120 & $6.94 \pm 0.02^{\mathrm{c}}$ \\
135 & $7.00 \pm 0.01^{\mathrm{c}}$ \\
150 & $7.05 \pm 0.03^{\mathrm{c}}$ \\
165 & $7.10 \pm 0.10^{\mathrm{c}}$ \\
180 & $7.11 \pm 0.92^{\mathrm{d}}$ \\
195 & $7.12 \pm 0.11^{\mathrm{d}}$ \\
210 & $7.14 \pm 0.02^{\mathrm{d}}$ \\
\hline
\end{tabular}

Values are shown as mean \pm SD of triplicates;

Means in the row without a common superscript letter differ $(p<0.05)$.

Sensory evaluation of spined anchovy sauce: Sensory testing of a fishery product is an important aspect to determine its acceptability among general consumers. A number of factors are responsible for sensory acceptability of spined anchovy sauce that includes colour, flavour, taste (e.g. saltiness, bitterness, sweetness, sourness and umami), clearness, liquidity, and overall acceptability. Based on our previous findings (Faisal et al. 2013), we choose $25 \%$ salt for sauce preparation and minimized the excessive saltiness of the product. Table III shows the results of the sensory evaluation obtained from the study. After end of fermentation, samples were kept in the direct sunlight for 15 days for aging that resulted in a deep brown coloured liquid. It was 
observed that the highest score was found for liquidity, followed by overall acceptability and taste. Flavour attribute had the lowest average score of $5.52 \pm 0.19$. Although the flavour attribute was relatively low, its value may be considered as reasonably good. In the fish sauces, the undesirable fishy odour is primarily associated with the volatile compounds such as ammonia, mono-, di-, and tri-ethylamine (Gram and Huss 1996). It is well known that trimethylamine gives a distinctive fishy, amine-like odour that derives from TMAO, and highly abundant in marine fish (Gram and Huss 1996). In the present study, panelists recorded slight fishy odour in the fish sauce, and were judged to be acceptable. Another related factor is lipid content in the end product. Although we did not estimate thiobarbituric acid reactive substances or peroxide values for our sample, relatively similar amount of lipid content present in the raw material and end product indicate its considerably stable condition. The traditional Thai fish sauce nam-pla had a fishy, cheesy and rancid odor (Sanceda et al. 1984). The high score for flavour attribute is an indication of good quality of the obtained fish sauce. This attribute generally comes from free amino acids, peptides and organic acids found in the end product (Osako et al. 2005).

Table III. Sensory evaluation of salt-fermented spined anchovy sauce

\begin{tabular}{lc}
\hline Attribute & Acceptance score \\
\hline Colour & $5.81 \pm 0.35$ \\
Flavour & $5.52 \pm 0.19$ \\
Taste & $6.02 \pm 0.09$ \\
Clearness & $5.88 \pm 0.35$ \\
Liquidity & $6.50 \pm 0.10$ \\
Overall acceptability & $6.25 \pm 0.25$ \\
\hline
\end{tabular}

\section{Conclusions}

Fish sauce prepared from an under-utilized marine fish spined anchovy showed characteristic colour, flavor, and taste with medium quantity protein and high minerals. The technology used for fish sauce production was traditional and used earthen jars that is more or less similar to that of shidhal processing in Bangladesh. So, the processors in Bangladesh can easily adapt this technology to produce fish sauce locally. Thus, the domestic consumers can get a good quality product, and open ways for the introduction of various value-added products from other underutilized fishery resources of Bangladesh.

\section{Literature Cited}

Alam, A.K.M.N., 2007. Participatory training of trainers: A new approach applied in fish processing. Bangladesh Fisheries Research Forum, Dhaka, 328 p.

Al-Jedah, J.H., M.Z. Ali and R.K. Robinson, 2000. The inhibitory action of spices against pathogens that might be capable of growth in a fish sauce (mehiawah) from the Middle East. Int. J. Food Microbiol., 57: 129-133

Anihouvi, V.B., G.S. Ayernor, J.D. Hounhouigan and E. Sakyi-Dawson, 2006. Quality characteristics of lanhouin: a traditionally processed fermented fish product in the Republic of Benin. Afr. J. Food Agric. Nutr. Dev., 6: 1-15. 


\section{PHYSICOCHEMICAL, MICROBIOLOGICAL AND SENSORY CHARACTERISTICS OF FISH SAUCE}

Anihouvi, V.B., F. Saali, E. Sakyi-Dowsan, G.S. Ayenor and J.D. Honhouigan, 2011. Response surface method for optimizing the fermentation condition during the processing of cassava fish (Pseudotolithus sp.) into Lanhouin. Int. J. Eng. Sci.Technol., 3: 7085-7095.

Antonacopoulos, N. and W. Vyncke, 1989. Determination of volatile basic nitrogen in fish: a third collaborative study by the West European Fish Technologists' Association (WEFTA). Zeitschrift Fur Lebensmittel-Untersuchung Und-Forschung, 189: 309-316.

Beddows, C.G., 1998. Fermented fish and fish products. In: World BJB. Editor Microbiology of Fermented Foods. Vol. 1, $2^{\text {nd }}$ ed. London: Blackie Academic and Professional. 416-440.

Bersamin, S.V. and R.S.J. Napugan, 1961. Preliminary studies on the comparative chemical composition of the different commercial brands of Patis in the Philippines. J. Fish., 2: 151-157.

Besas, J.R. and E.I. Dizon, 2012. Influence of salt concentration on histamine formation in fermented tuna viscera (Dayok). Food Nutr. Sci., 3: 201-206.

Chaveesuk, R., 1991. Accleration of Fish Sauce Fermentation Using Proteolytic Enzymes. Department of Food Science and Agricultural Chemistry, McGill University Libraries. 200 p.

Cho, Y.J., Y.S. Im, H.Y. Park and Y.J. Choi, 2000. Quality characteristics of Southeast Asian saltfermented fish sauces. J. Korean Fish. Soc., 33: 98-102.

Connell, J.J., 1995. Control of Fish Quality, $4^{\text {th }}$ edn. Fishing News Books Ltd. England. 35 p.

Desniar, P.D. and W. Wijatur, 2009. The influence of salt concentration on peda chubb mackerel (Rastrelliger $\mathrm{sp}$ ) with spontaneous fermentation. J. Pengol. Perik. Indonesia,12: 73-87.

Faisal, M., M.N. Islam, M. Kamal and M.N.A. Khan, 2013. Production of fish sauce from low cost small freshwater fish and their qualitative evaluation. Progr. Agric., 24: 171-180.

Food and Drug Administration (FDA), 2004. Code of federal regulations 21 CFR 161 Subpart B Section 161.190. United State Food and Drug Administration, USA.

Gram, L. and H.H. Huss, 1996. Microbiological spoilage of fish and fish products. Int. J. Food Microbiol., 33: 121-137.

Hjalmarsson, G.H., J.W. Park and K. Kristbergsson, 2007. Seasonal effects on the physicochemical characteristics of fish sauce made from capelin (Mallotus villosus). Food Chem., 103: 495-504.

Ijong, F.G. and Y. Ohta, 1996. Physicochemical and microbiological changes associated with Bakasang processing-A traditional Indonesian fermented fish sauce. J. Sci. Food Agric., 71: 69-74.

Islami, S.N., M.S. Reza, M.A. Mansur, M.S. Hossain, F.H. Shikha and M. Kamal, 2014. Rigor index, fillet yield and proximate composition of cultured striped catfish (Pangasianodon hypophthalmus) for its suitability in processing industries in Bangladesh. J. Fish., 2: 157-162.

Kim, G.B., Y.S. Im, K.W. Lee and Y.J. Cho, 1999. Changes of components in salt fermented northern sand lance, Ammodytes personatus sauce during fermentation. J. Korean Fish. Soc., 32: 693-698.

Lawrie, R.A., 1998. Meat Science. $6^{\text {th }}$ edn. Cambridge: Woodhead Publishing Ltd. United Kingdom.

Lopetcharat K., Y.J. Choi, J.W. Park and M.A. Daeschel, 2001. Fish sauce products and manufacturing: A Review. Food Revi. Int., 17: 65-88.

Lopetcharat, K. and J.W. Park, 2002. Characteristics of fish sauce made from pacific whiting and surimi by products during fermentation stage. J. Food Sci., 67: 511-516.

Ly, D.S. Mayrhofer, J.-M. Schmidt, U. Zitz and K.J. Domig, 2020. Biogenic Amine Contents and Microbial Characteristics of Cambodian Fermented. Foods, 9: 198.

Mannan, M., S.R. Islam, M.H. Osman, M.K. Rahman, M.N. Uddin and M.S. Reza, 2020. Antibacterial activity of oxytetracycline on microbial ecology of Nile tilapia (Oreochromis niloticus) gastrointestinal tract under laboratory condition. Aquac. Res., 51: 2125-2133.

Mansur, M.A., 2007. A review of different aspects of fish fermentation in Bangladesh. Bangladesh $J$. Prog. Sci. Tech., 5: 185-190.

Mansur, M.A., M.S. Rahman, M.N.A. Khan, M.S. Reza, L. Sadia and R. Wahab, 2014. Studies on the quality attributes and safety aspect of semi-fermented fish product. Indian J. Geo-Mar. Sci., 43: 949954.

Moini, S. and A. Koochekian, 2003. Production of fish sauce from Caspian Sea kilka, with use of traditional, microbial and enzymatic methods. Iranian J. Fisheries Sci., 7: 79-94. 
Nayeem, M.A., K. Pervin, M.S. Reza, M.N.A. Khan, F.H. Shikha and M. Kamal, 2010a. Present status of handling, transportation and processing of traditional dried Punti (punti shutki) and semi-fermented fish (chepa shutki) products in Mymensingh district. J. Agroforestry Environ., 4: 13-16

Nayeem, M.A., K. Pervin, M.S. Reza, M.M.A. Khan, M.N. Islam and M. Kamal, 2010b. Marketing system of traditional dried and semi-fermented fish product (chepa shutki) and socio-economic condition of the retailers in local markets of Mymensingh region, Bangladesh. Bangladesh Res. Publication J., 4: 69-75.

Osako, K., M.A. Hossain, K. Kuwahara, A. Okamoto, A. Yamaguchi and Y. Nozaki, 2005. Quality aspect of fish sauce prepared from underutilized fatty Japanese anchovy and rabbit fish. Fish. Sci., 71: 1347-1355.

Peralta, E., H. Hatate, D. Kawabe, R. Kuwahara, S. Wakamatsu, T. Yuki and H. Murata, 2008. Improving antioxidant activity and nutritional components of Philippine Salt-fermented shrimp paste through prolonged fermentation. Food Chem., 111: 72-79.

Reza, M.S., M.A.J. Bapary, C.T. Ahasan, M.N. Islam and M. Kamal, 2009. Shelf life of several marine fish species of Bangladesh during ice storage. Int. J. Food Sci. Technol., 44: 1485-1494.

Roy, D., R.K. Majumdar, S.K. Maurya, H.H. Tripathi, B. Dhar and B.M. Priyadarshini, 2014. Understanding of traditional knowledge and characterization of telesech-A fermented fish product of Tripura state. Indian J. Nat. Prod. Res., 5: 351-358.

Sanceda, N.G., T. Kurata and N. Arakawa, 1984. Fractionation and identification of volatile compounds in Patis, a Philippine fish sauce. Agric. Biol. Chem., 48: 3047-3052.

Sanchez, P.C., 2001. Microorganisms in traditional fermented foods: Resources for biotechnological development. p. 143-157. In: B.H. Nga, H.M. Tan and K.I. Szuki (eds.). Microbial-diversity in Asia: Technology and Prospects. World Scientific, Singapore, 272 p.

Soewarno, S., 1985. Organoleptic Evaluation for Food Industry and Agricultural Products (Penilaian Organoleptik untuk Industri Pangan dan Hasil Pertanian). Jakarta : Karya Aksara.

Taorem, S. and C.H. Sarojanlini, 2012. Effect of temperature on biochemical and microbiological qualities of Ngari. Nature Sci., 10: 32 - 40.

Thapa, N., J. Pal, and J.P. Tamang, 2004. Microbial diversity in ngari, hentak and tungtap fermented fish products of Nort-East India. World J. Microbiol. Biotechnol., 20: 599-607.

Tungkawachara S., J.W. Park and Y.J. Choi, 2003. Biochemical properties and consumer acceptance of Pacific whiting fish sauce. J. Food Sci., 68: 855-860.

Ulfah, K.N., 2013. Determination of biochemical quality in Malaysian fermented products. $J$. Environmental Res. Dev., 7: 1224-1227.

Wilaipan, P., 1990. Halophilic bacteria producing lipase in fish sauce. MSc thesis. Bangkok, Thailand: Chulalongkorn Univ.

Wichaphon, J., W. Posri, Q. Assavanig, C. Thongthai and S. Lertsiri, 2013. Categorization of Thai fish sauce based on aroma characteristics, J. Food Qual., 36: 91-97.

Zheng, B., Y. Liu, X. He, S. Hu, S. Li, M. Chen and W. Jiang, 2017. Quality improvement on half-fin anchovy (Setipinna taty) fish sauce by Psychrobacter sp. SP-1 fermentation. J. Sci. Food Agri., 97: 4484-4493. 